\title{
Ethics in Project Management Research on Values-Based Leadership in Project Driven Arenas
}

\author{
Loran Walker \\ Capella University \\ loran.walker@capella.edu
}

\author{
William A Moylan \\ Construction Management, \\ School of Visual \& Built Environments \\ College of Technology \\ wmoylan@emich.edu
}

DOI 10.5592/otmcj.2014.3.6

Research paper

\section{Keywords}

THE PAPER ADDRESSES THE VALUES-BASED LEADERSHIP SKILLS, VALUES AND CONCEPTS OF ETHICAL PROJECT MANAGEMENT PROFESSIONALS, AND, CONSIDERS THE APPLICABILITY OF THIS LEADERSHIP CONSTRUCT TO THE PROCESSES OF MANAGING MAJOR PROJECTS IN DIFFERENT INDUSTRIES AND APPLICATIONS. The purpose of the research study is to determine the suitability of a values-based leadership approach for leading project teams, with a focus on improving the partnerships within industrial programs. The main research question addressed is: "Can the application of values-based leadership skills, values and concepts improve the processes of project management, especially within project-driven industries?" A follow on to this research question is the hypothesis of: "Values-based leadership skills, values, and concepts are highly applicable to the processes of project management, in particular, in the leading of programs from concept through completion." The study assesses the eleven leadership values postulated in the criteria for the Malcolm Baldrige National Quality Award (2013) as means to establish an ethical rubric within project-driven industries. Additionally, the paper reviews the six core principles of values-based leadership postulated by G.W. Fairholm (1998). The research study uses a quantitative approach (survey) to assess the critical elements of this topic. On previous research performed on this topic, a mixed methods approach was found appropriate to identify the values shared between the leader and followers (qualitative), review the values-base for the particular application (quantitative), and compare the leader's ethical values with the organization (mixed methods). 


\section{INTRODUCTION}

Research on values-based leadership [VBL] and ethics in project-based industries and applications pose interesting challenges. In the past decade, ethics and professional conduct has become a "hot" topic in academia (especially in graduate level programs of business, engineering and management), within professional society discussion circles, and, throughout all levels of government. Unfortunately there is a paucity of substantial research available that points the way for professional conduct improvement.

In performing his dissertation research on ethics in construction and VBL (Moylan, 2005), the author noted one of the major areas requiring additional study is the topic of this research paper. The research study expands on the applicability of values-based leadership to other project-driven industries in order to show the relevance of ethics and professional conduct across the spectrum of project-driven industries. Suggested project-driven industries include information systems / telecommunications, new product development, and manufacturing. Further, the study uses a similar survey instrument following the Malcomb Baldrige (2013) criteria on interrelated core values and concepts of leadership, so that industry comparisons could be made.

The paper expands the application arena on research on ethics in project management based on using VBL as the analysis rubric. Key project-driven industries and applications are considered with the results being compared and contrasted with the original research on construction industry results. The paper summarizes the literature on VBL applicable to project management applications, and, the research study conducted by the authors.

\section{Review of Values-Based Leadership}

The study of leadership has evolved from a focus on the actions of a heroic leader to a broader view that considers leadership as an influential exercise in any interpersonal relationship and as a social function required to achieve organizational goals. During the 1990 , the types of scholarly articles on leadership have transitioned from a strong emphasis on empirical research and some theoretical discussions to a balance of empirical and theoretical with some discussion on leadership methods. The concepts, values, and skills of Values-Based Leadership emerged from the path-goal theory and subsequently the transformational leadership approach that requires a strong trusting and ethical partnership between the leader and team members (Northouse, 2013). The following sections overview the concepts, values and skills of Values-Based Leadership [VBL].

\section{Primer on Values-Based Leadership}

The first major underpinning of ethical leadership is the inherent values shared between the leader and their followers. The values-base, which the leader advocates for the subordinates' benefit, is a function of the leader's personal ethical values and a reflection of the organization's structure and systems (Viinamäki, 2012). For example, the "duty-honor-country" code of the US Military Academy at West Point is the life blood of all the brave women and men who form the thin gray line (Winn, 2014). The leader acts to form a supportive team culture that leads to collective progress, enhanced personal esteem, and improved self-determination (Hackett \& Wang, 2012). The core principles of values-based leadership meld on the loyalty the followers develop for their cause, each other, and their leader.

\section{Core Principles of Values- Based Leadership}

G.W. Fairholm postulated six centric principles of values-based leadership (1998). The first principle relates to the leader's role in stakeholder development to transform himself, his followers, and the organization to focus on accomplishing the vision with creativity and enthusiasm. The second principle considers the leader's role in creating this vision that epitomizes the core values of the leader and helps target the follower's actions. The third principle relates how the leader creates a culture supportive of the core values that contribute to the team achieving its personal and group goals. The fourth principle of this sextet correlates the leader's preparation for the personalized relationships with his or her followers that amalgamate the personal values, self-purpose, and methods with each other in a councillike, two-way exchange (as opposed to a one-way counseling exercise). The next principle requires the values-based leader to be a teacher of his or her followers, coaching on improving personal relationships, work skills, and attitudes to enable, empower, and energize them to greater performance. The sixth principle concludes with the values-based leader's dual goal of producing highperformance and self-directed followers with an inherent loyalty to the organization and the group mission. These six principles of G.W. Fairholm constitute the philosophical base for values-based leadership. Although values-based leadership is appropriate for many situations, it is most applicable to leading transformational change initiatives, which require changes in corporate culture and personal behavior to be effective (Hacket \& Wang, 2012, Karakas \& Sarigollu, 2012, Nicolae \& Nocolae, 2013).

\section{Leading Transformational Change}

The primary role of leaders is leading transformational change (Essawi 
\& Tilchin, 2012), conscious that the typical over managed and under led American firms today (Barrett, 2011) are not up to the challenge. Herein is the argument for value-based leadership as the preferred method for leading change (Lestrange \& Tolstikov-Mast, 2013). Values-based leaders consciously choose to follow a servant style of leadership, who lead by example and trust rather than command and fear, coupled with the unbridled moral courage, constant respect and desire to serve others. Values-based leaders are the most successful in implementing holistic, ongoing change efforts in which they gain top executive support without the need for strict definition of requirements. During the pre-launch phase of a change initiative, it is imperative for the leader to "walk the talk" in extolling their personal values with the organizational vision, especially in articulating the needs for the particular change (Ahu, Ettner, \& Loupin, 2012). The necessary influencing by the leaders of their followers to perform what they consider to satisfy her/his own values while serving the needs of the group mission becomes the most challenging aspect of vision-based leadership. The change leader acts positively on the follower's values, perceptions, and behavior to elicit the appropriate response/s that consequently satisfy the group mission and organizational vision (Udani \& Lorenzo-molo, 2013). Values-based leaders conscripted to lead transformational changes in fastpaced industries will require a broad network of colleagues and cohorts.

\section{Value Confederations}

The hyper-competitive pressures, strains on resources, and emerging market requirements beyond the capabilities of many firms cause the nimble company to form closer relationships and alliances with its customers and suppliers. The benefits of improved coordination and information flow, disciplined product development, and system-wide solutions require access to vital knowledge and competencies not widely available. A web-like constellation of the necessary expertise, suppliers, distributors, and customers is essential to creating the extended enterprise, with its own set of core values that will meld all of the talents to satisfy the overarching vision (VanHise, Koeplin \& Whitty, 2013). The emergence of the "value confederation" of networked companies based on their shared values allows each entity to specialize on its core competencies, leveraging its strengths, and gaining advantage for its weaknesses (Essawi \& Tilchin, 2012). From a values-based leadership perspective, this construct of a value confederation affords each component firm the opportunity to satisfy its individual needs and desires (building personal esteem) while working toward the group vision, goals, and mission (shared values). Moreover, the protective umbrella of the networked enterprise allows the assembled project team to share in the glory (gaining intrinsic goal satisfaction) without having to suffer the risks entirely on its own (creating meaningful team work). Trustworthiness, the fifth element of values-based leadership, forms the defining culture for managing and leading complex organizations.

\section{The Research Study}

The subject research study used a quantitative approach to assess the critical elements of this topic. In researching values-based leadership (Karimi, Safari, Hashemi \& Kalantar, 2014), a quantitative approach is considered appropriate to review the values-base for the several projecttype applications, and subsequently to compare and contrast the results with past VBL studies using a similar survey instrument.

The main research question addressed in the study is "Can the application of values-based leadership skills, values and concepts improve the processes of project management for a variety of industries and applications?" A follow on to this research question is the hypothesis of "Values-based leadership skills, values, and concepts are highly applicable to the processes of project management, in particular, in the leading of programs from concept through completion."

The criteria for performance excellence embodied in the Malcolm Baldrige National Quality Award (2013) offered a framework to develop the list of questions for the quantitative survey. Leadership, one of the seven categories that make up the core values and concepts, "examines how the organization's senior leaders address values, directions, and performance expectations, as well as a focus on customers and other stakeholders, empowerment, innovation, and learning" (Baldrige, p. 13). (The other categories include strategic planning, customer and market focus, measurement, analysis and knowledge management, human resources focus, process management, and business results.)

From the Baldrige (2013) criteria on the interrelated core values and concepts, the authors developed a list of the respondent items that addressed the skills, values, and concepts of values-based leadership. These items include the following quantitative elements: (1) visionary leadership, (2) customer-driven excellence, (3) organizational and personal learning, (4) value of employees and partners, (5) agility, (6) focus on the future, (7) management for innovation, (8) management by fact, (9) social responsibility, (10) focus on results and creating value, and (11) systems perspective. These items formed the core of the survey instrument.

\section{Research Results on Ethics in Project Management}

This section summarizes the quantitative research results performed on ethics in project management for several industries. 


\section{Group Profile}

The profile of the Group respondents by "Industry Category" and by "Years of Experience" is as follows:

\begin{tabular}{|c|c|}
\hline Industry Category & $\begin{array}{c}\text { Number of } \\
\text { Respondents }\end{array}$ \\
\hline Aerospace \& Defense & 2 \\
\hline Construction & 8 \\
\hline Consulting & 10 \\
\hline Education & 8 \\
\hline Finance & 16 \\
\hline Government & 11 \\
\hline Healthcare & 10 \\
\hline Human Resources & 3 \\
\hline Information Systems & 58 \\
\hline Manufacturing & 5 \\
\hline Marketing & 3 \\
\hline Mining, Oil \& Gas & 3 \\
\hline Pharmaceutical & 4 \\
\hline Retail & 1 \\
\hline Service Industry & 7 \\
\hline Transportation & 3 \\
\hline Utilities Industry & 4 \\
\hline OTHER & 28 \\
\hline Total & 184 \\
\hline
\end{tabular}

\begin{tabular}{|c|c|}
\hline Years Experience & $\begin{array}{c}\text { Number of } \\
\text { Respondents }\end{array}$ \\
\hline NONE [o] & 31 \\
\hline 1 to 5 & 86 \\
\hline 6 to 10 & 41 \\
\hline 11 to 15 & 15 \\
\hline 16 to 20 & 7 \\
\hline $21+$ & 5 \\
\hline Total & 184 \\
\hline
\end{tabular}

\section{Survey Results}

The 184 responses from the Group Survey yielded the response results to the eleven survey questions concerning Project Management Values and Beliefs, shown in Exhibit 1.

\section{General Overview of Data Finding}

As in the original research survey the majority agree on all Baldrige Quality Award criteria. All eleven questions point to an engaged management team, valued employees, innovation, learning, with the reason for existence being excellent products or services rendered to the customer.

However, within the data (Exhibit 1.) note there are some weaknesses that need to be discussed. Some of the weak points are:

Visionary Leadership from the CEO

Management by Fact

Systems Perspective

\section{Visionary Leadership}

Within this question approximately 70 percent of the respondents believe their chief executive officer is a visionary for the organization however there is 30 percent that is either neutral on the topic or disagree that their CEO is setting the appropriate way forward for the organization.

Management by Fact

Within this question approximately 65 percent of the respondents believe that facts are the basis for understanding success or failure within the organization. However the other 35 percent fall into being neutral or negative on the use of metrics within an organization. This may show an aberration between policy and practice within the organization.

\section{Systems Perspective}

Within the question approximately 79 percent of the respondents believe that a systems perspective is needs to be in place for success. Again this integration question shows either respondent are neutral or negative on this type of viewpoint for success within the organization.

The strongest points of the survey are:

- Organizational and Personal Learning

> Valuing Employees and Partners

- Focus on the future

Managing for innovation
These points could be further placed in two categories, personnel and management. Although the overarching theme of the survey is the management of the organization these 4 questions show that much of the success of an organization stem from engaged personnel and visionary leadership. The ability to learn from each other, from past successes and failures as well as keeping an eye on the future is paramount in sustaining a successful organization.

\section{Comparison of Two Groups: \\ Construction Industry and Information Systems}

The largest group represented in the new data is project managers employed in the Information Systems field. When separating this group from the rest and comparing it to the original construction management group (Exhibits 2 and 3) the overall responses are still positive on all eleven Baldrige criteria. However, there are subtle variations that may show how the culture of each industry area may diverge from the overall viewpoint of the group at large.

The information systems group has no neutrality on the value of employees learning and employee value respectively. This employee-centric view may show a cultural perspective on the concept of "knowledge worker" and the ability of information systems specialists to research and come up with solutions to problems that may arise within a project. Also there is more variance on management's vision and basing the success of the organization on metrics. The information systems group shows more neutrality and negativity toward management vision and metrics being used to rate performance.

Juxtaposed to this the construction group has very little neutrality and negativity on management's vision and metrics-based performance. This may speak to the construction industry culture in that the final result are tangible assets compared to information systems construction of computer 
services that reside in the Ether. This may also show a difference in approach to a project where in the construction industry there may be less collaboration and more top-down communication and/or direction to render a structure whereas in the information systems field there is a high amount of collaboration to arrive at solutions to issues that arise during the execution of a project.

It may even be a comparison between a matured industry such as construction and the relatively new information systems industry. Perhaps additional questions along this path may substantiate these conjectures.

\section{Conclusions}

This research and surveys show that there is broad agreement on the 11 Baldrige Quality Award criteria amongst all the participants no matter the industry they are working in. Because of the sample size of both the earlier and present survey more succinct conclusions cannot be made however some guidance for future research is shown through contrast and comparison of the two samples.

Based on the industry/business there is a divergence in opinion on the quality criteria. In this case there seems to be more questioning of the value of management's impact on the organization by the information systems groups compared to the construction industry group. Whereas individualism may be more of a part of the information systems group compared to the construction industry group.

Again the new survey moves this research forward and gives the researchers various pathways to pursue on valuebased learning. A larger sample is needed to explore more fully the industry-based divergence from the overall view and to see if there is a large divergence with the amount of experience a project manager has on the job. A sample that is more statistically significant is needed to ascertain these questions and to see if the overall viewpoint changes with it.

\section{Recommendations}

For construction sites in Abuja to have the managerial potentials to manage diverse workforce having seen the shortfall of the traditional site management as it relates to cultural diversity; the following strategies are therefore recommended:

- Appropriate programme should be formally developed within the organisations whereby all the workers will be trained on diversity management and cultural awareness.

> Construction firms should adopt the Hofstede cultural dimension as a management tool to manage the diverse workforce.

- Managers should know the cultural dimension they belong to.

- Organisations should develop employee survey as a re-evaluation technique designed towards achieving extensive reporting of the cultural diversity of the organisations' workforce. By means of effective and consistent performance measurements in form of re-evaluation technique of comparing their organisations productivity to that of others.

- As much as possible construction firms should create cultural awareness on sites translating the safety slogans, sign posts in different languages that are representative of the workforce.

\section{References}

Ahn, M. J., Ettner, L. W., \& Loupin, A. (2012). Values v. traits-based approaches to leadership: Insights from an analysis of the aeneid. Leadership \& Organization Development Journal, 33(2), 112-130.

Baldrige National Quality Award. (2013). 20132014 Criteria for performance excellence. Gaithersburg, MD: National Institute of Standards and Technology.

Barrett, R. (2011). Evolutionary coaching. Interbeing, 5(1), 57-59. Retrieved from

Essawi, M., \& Tilchin, O. (2012). Structural approach to changing organizational cultural values. International Journal of Business and Social Science, 3(20)
Fairholm, G. W. (1998). Perspectives on leadership: From the science of management to its spiritual heart. Westport, CT: Quorum Books.

Hackett, R. D., \& Wang, G. (2012). Virtues and leadership. Management Decision, 50(5), 868-899.

Karakas, F., \& Sarigollu, E. (2012). Benevolent leadership: Conceptualization and construct development. Journal of Business Ethics, 108(4), 537-553.

Karimi, A., Safari, H., Hashemi, S. H., \& Kalantar, P. (2014). A study of the baldrige award framework using the applicant scoring data. Total Quality Management \& Business Excellence, 25(5-6), 461.

Lestrange, J. J., \& Tolstikov-Mast, Y. (2013). Can global organizations use values-based leadership to combat bribery and corruption? Journal of Leadership, Accountability and Ethics, 10(4), 41-56.

Moylan, W.A. (2005). Building ethics in construction partnerships: An analysis of values-based leadership. (Doctoral dissertation, Capella University, 2005). Dissertation Abstracts International, DAI-A 66/03, p. 1075, Sept. 2005. (UMI No. AAT 3168176).

Nicolae, M., Ion, I., \& Nicolae, E. (2013). The research agenda of spiritual leadership. where do we stand? Revista De Management Comparat International, 14(4), 551-566.

Northouse, P. G. (2013). Leadership: Theory and practice -6 th edition. Thousand Oaks, CA: Sage Publications, Inc.

Udani, Z. A., S., \& Lorenzo-molo, C. (2013). When servant becomes leader: The corazon C. aquino success story as a beacon for business leaders. Journal of Business Ethics, 116(2), 373-391.

VanHise, J., Koeplin, J., S.J., \& Whitty, M. D. (2013). Honesty and ethics in business: The task of educators jesuit business education as a model. Business Renaissance Quarterly, 8(1), 1-16.

Viinamäki, 0. (2012). Why leaders fail in introducing values-based leadership? an elaboration of feasible steps, challenges, and suggestions for practitioners. International Journal of Business and Management, 7(9), 28-39.

Winn, G. L. (2014). Safety leadership: Insights from military research. Professional Safety, 59(1), 32-38. 


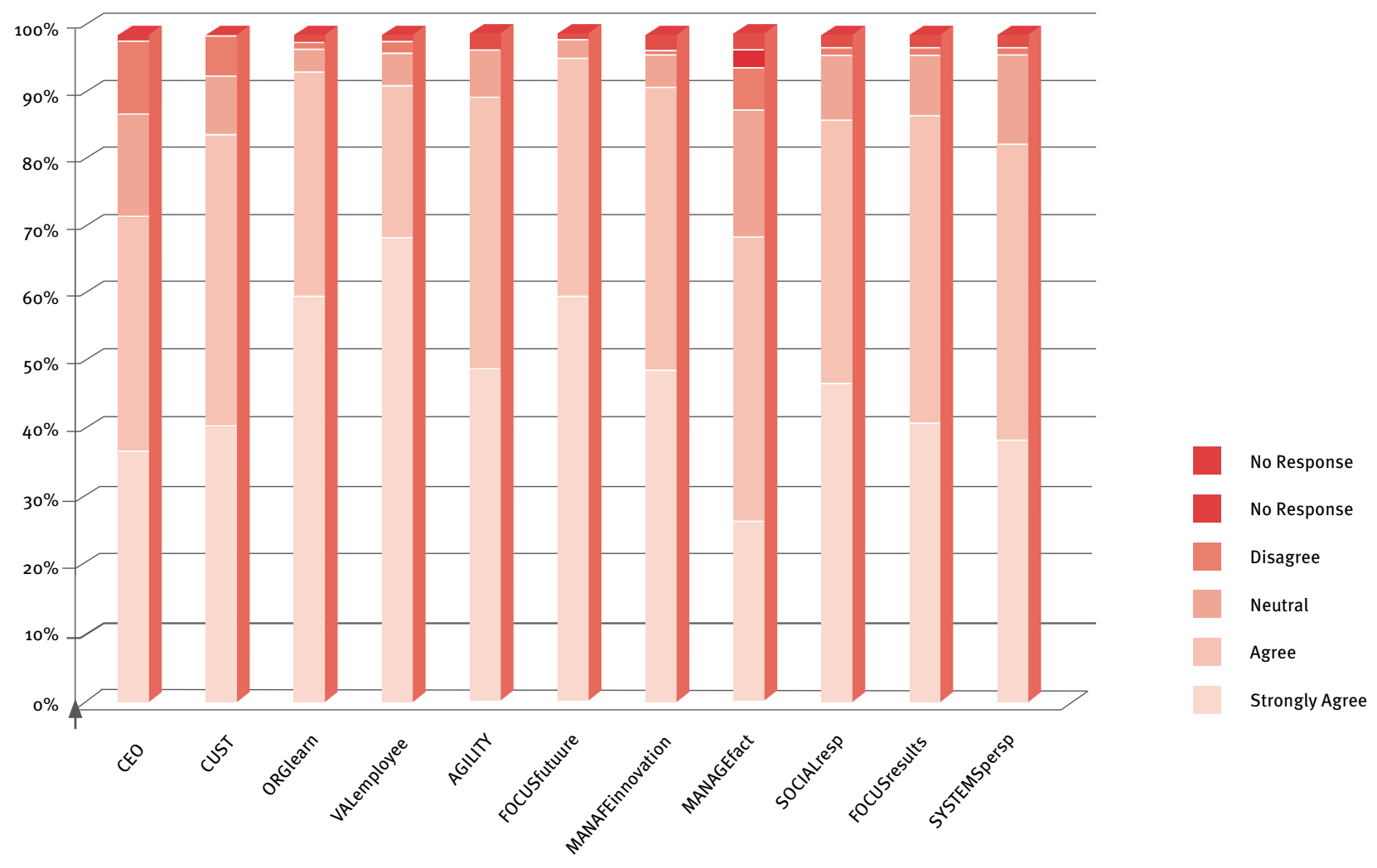

Exhibit 1 Overall Data New Survey

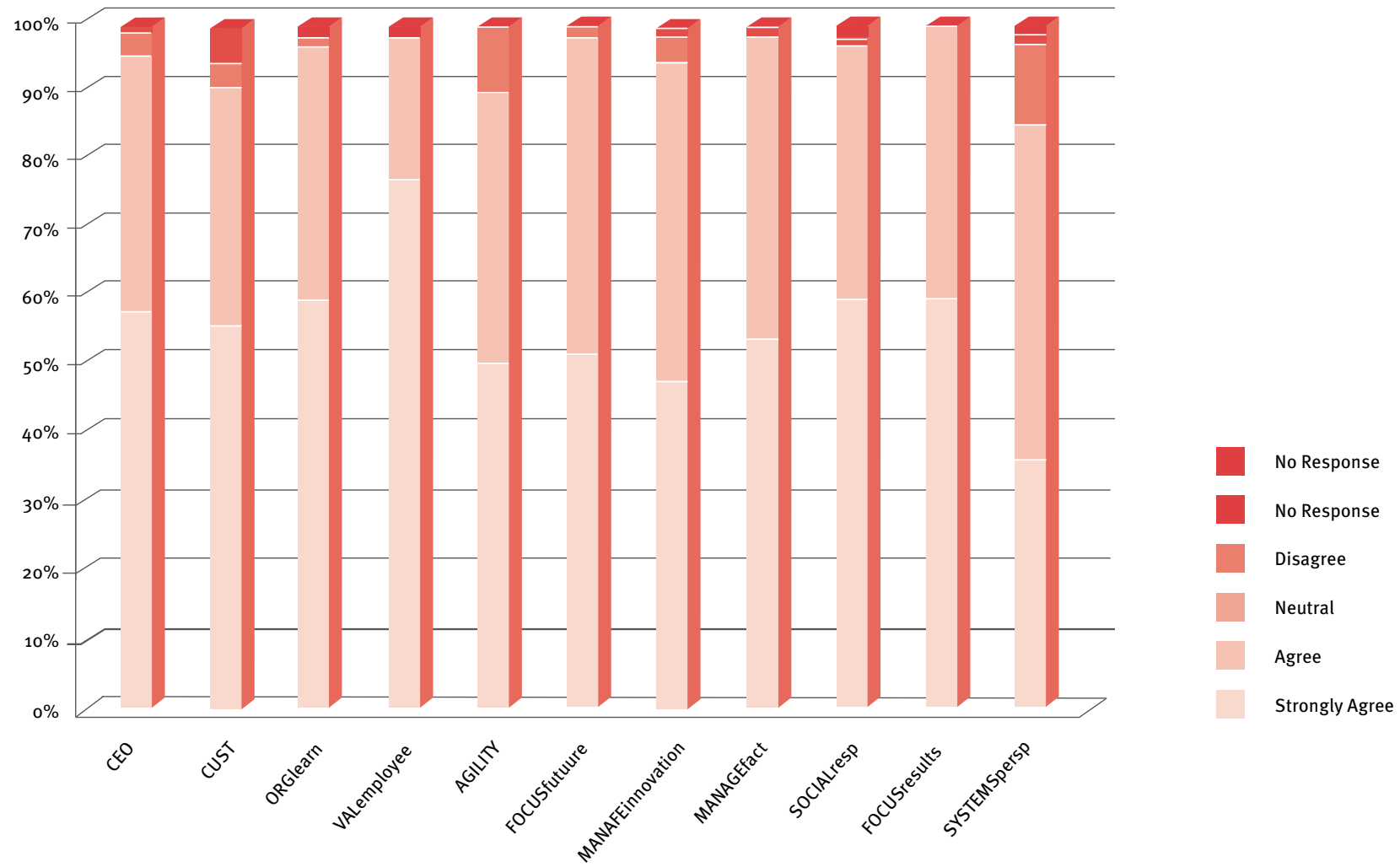

Exhibit 2 Construction Industry Survey with Merged Disagree and Agree Categories 


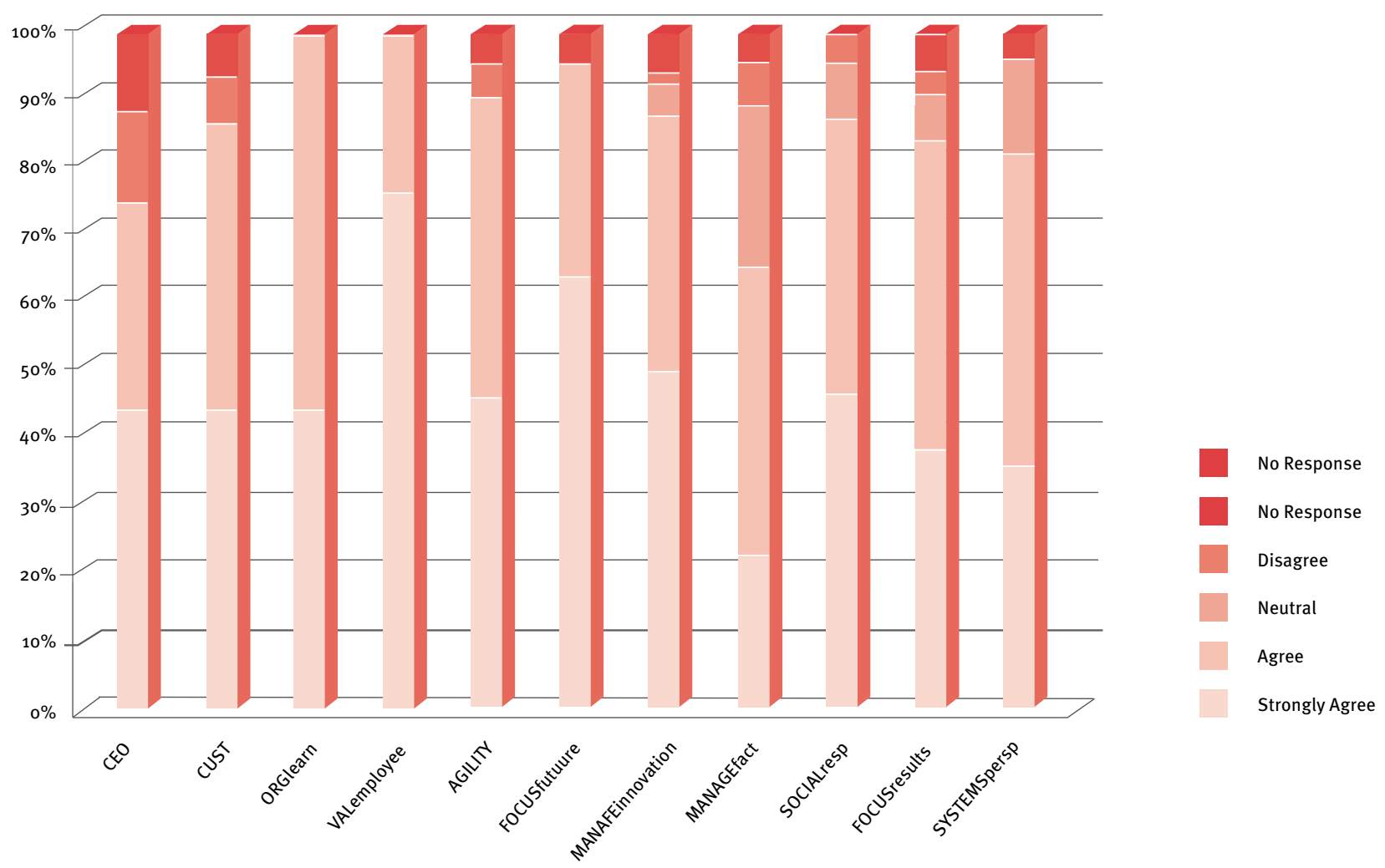

Exhibit 3 New Survey - Information Systems Isolated

\begin{tabular}{|c|c|c|c|c|c|c|c|c|c|c|c|}
\hline $\begin{array}{c}\text { Survey } \\
\text { Item }\end{array}$ & คी & है & 兽 융 & 罩 & 常 & 끌 을 & 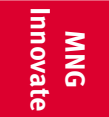 & 華亘 & 密 & 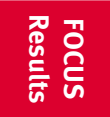 & $\frac{0}{\frac{n}{n}} \frac{n}{3}$ \\
\hline \multicolumn{12}{|l|}{ RESPONSE } \\
\hline \multirow[t]{2}{*}{$\begin{array}{l}\text { Strongly } \\
\text { Agree }\end{array}$} & 70 & 77 & 112 & 128 & 92 & 112 & 92 & 51 & 90 & 77 & 73 \\
\hline & $38.04 \%$ & $41.85 \%$ & $60.87 \%$ & $69.57 \%$ & $50.00 \%$ & $60.87 \%$ & $50.00 \%$ & $27.72 \%$ & $48.91 \%$ & $41.85 \%$ & $39.67 \%$ \\
\hline \multirow[t]{2}{*}{ Agree } & 65 & 81 & 62 & 43 & 75 & 66 & 78 & 78 & 71 & 85 & 81 \\
\hline & $35 \cdot 33 \%$ & $44.02 \%$ & $33.70 \%$ & $23.37 \%$ & $40.76 \%$ & $35.87 \%$ & $42.39 \%$ & $42.39 \%$ & $38.59 \%$ & $46.20 \%$ & $44.02 \%$ \\
\hline \multirow[t]{2}{*}{ Neutral } & 29 & 16 & 7 & 8 & 13 & 5 & 9 & 35 & 18 & 17 & 26 \\
\hline & $15.76 \%$ & $8.70 \%$ & $3.80 \%$ & $4.35 \%$ & $7.07 \%$ & $2.72 \%$ & $4.89 \%$ & $19.02 \%$ & $9.78 \%$ & $9.24 \%$ & $14.13 \%$ \\
\hline \multirow[t]{2}{*}{ Disagree } & 18 & 10 & 1 & 3 & 0 & 0 & 1 & 14 & 2 & 2 & 2 \\
\hline & $9.78 \%$ & $5.43 \%$ & $0.54 \%$ & $1.63 \%$ & $0.00 \%$ & $0.00 \%$ & $0.54 \%$ & $7.61 \%$ & $1.09 \%$ & $1.09 \%$ & $1.09 \%$ \\
\hline \multirow[t]{2}{*}{$\begin{array}{l}\text { Strongly } \\
\text { Disagree }\end{array}$} & 2 & 0 & 0 & 0 & 0 & 0 & 0 & 3 & 0 & 0 & 0 \\
\hline & $1.09 \%$ & $0.00 \%$ & $0.00 \%$ & $0.00 \%$ & $0.00 \%$ & $0.00 \%$ & $0.00 \%$ & $1.63 \%$ & $0.00 \%$ & $0.00 \%$ & $0.00 \%$ \\
\hline \multirow[t]{2}{*}{$\begin{array}{c}\text { No } \\
\text { Response }\end{array}$} & 0 & 0 & 2 & 2 & 4 & 1 & 4 & 3 & 3 & 3 & 2 \\
\hline & $0.00 \%$ & $0.00 \%$ & $1.09 \%$ & $1.09 \%$ & $2.17 \%$ & $0.54 \%$ & $2.17 \%$ & $1.63 \%$ & $1.63 \%$ & $1.63 \%$ & $1.09 \%$ \\
\hline \multirow[t]{2}{*}{ TOTALS } & 184 & 184 & 184 & 184 & 184 & 184 & 184 & 184 & 184 & 184 & 184 \\
\hline & $100.00 \%$ & $100.00 \%$ & $100.00 \%$ & $100.00 \%$ & $100.00 \%$ & $100.00 \%$ & $100.00 \%$ & $100.00 \%$ & $100.00 \%$ & $100.00 \%$ & $100.00 \%$ \\
\hline
\end{tabular}

